\title{
The Use of Think, Pair, Share Learning Method to Improve Vocabulary Mastery of the Second Class Students of Muhammadiyah Vocational High School, Salatiga in Academic Year 2011/2012
}

\author{
Ida Ubaidah Hidayati \\ Universitas Negeri Semarang \\ idaubaidah209@gmail.com
}

\begin{abstract}
The Aim of this research is to what extent does "Think, Pair, Share" use to improve the students' interest in the teaching-learning process for second class students of SMK Muhammadiyah Salatiga. The methodology of the study is classroom action research, where the writer as a teacher in the teaching-learning process, and writer had a partner as observer in learning activities. The objectives of the study are to what extent does "Think, Pair, Share" use to improve the vocabulary mastery, and to what extent does "Think, Pair, Share" use to improve the vocabulary mastery for the second year students of SMK Muhammadiyah Salatiga. The writer applied test, namely pre-test, and post-test. She implemented three cycles. Each consists of planning, implementation of the action, observation, and reflection. The finding shows that Think, Pair, Share learning method can improve vocabulary in teaching-learning process. It can be seen by the result of pretest and posttest in cycle I is 5,49 , cycle II is 6,32 , and cycle III is 8,03 . From the result is greater than t-table with $n=33$ is 0,42 . It means that the use of TPS can improve the student's vocabulary mastery.
\end{abstract}

ARTICLE HISTORY

Received 15 April 2017

Accepted 8 September 2017

\section{KEYWORDS}

Think; Pair; Share and

Vocabulary Mastery

\section{Introduction}

Vocabulary is one of the language aspects that are very important for English communication. If people have less vocabulary, they will not understand what others say. Essential vocabulary is needed to improve the four language skills such as listening, speaking, reading and writing. Vocabulary conveyed their argument and students can easily to do communication (Scott Thornbury, 2002:12). The students at SMK Muhammadiyah Salatiga (widely known as Muhammadiyah Senior Vocational School, Salatiga) get many problems to study the English language, especially for mastery of vocabulary in English. According to my observation the problems are various as follows: 1) an enthusiastic and active learning of students in participating still not visible, 2) the students rarely ask questions, although teachers often request that the students asked if there are things not clear, or less understood, 3) active in working on training issues English language learning are also still lacking, 4) lack of courage students to work on the problems in front of the class, 
5) students feel bored, because the learning is positioned only as a listener, 6) learning process is monotonous and less attractive, and 7) lack of student mastery to the subject matter of English especially in vocabulary. This illustrates the effectiveness of teaching and learning in the classroom is still less. Some students want to ask the teacher even though they did not know the meaning of vocabulary words in the sentences. In the process of learning English in SMK Muhammadiyah, Salatiga was found a situation when the teacher explains; the students were passive. However, after given some exercises most students cannot do about the material, they choose to cheat their friends. Based on the background above, the researcher formulates the following research questions:(1) what extent does "Think, Pair, Share" use to improve the students' interest in the teaching-learning process for second-year students? (2) to what extent does "Think, Pair, Share" use to improve the vocabulary mastery for the second year students of SMK Muhammadiyah Salatiga?

Related to the problem statement above, the objective of this research is then specified: (1) to find out whether TPS (Think, Pair, Share) learning method can improve the student's interest to study English of the second year students of SMK Muhammadiyah Salatiga. (2) to find out whether TPS (Think, Pair, Share) learning method can improve the vocabulary mastery of the second year students of SMK Muhammadiyah Salatiga.

The result of this research is expected to be useful information to (1) increase the teachers' knowledge of English and share experiences in improving vocabulary mastery using "think, pair, share" method; (2) encourage the teachers' colleagues in doing action research in improving their teaching as the professional practices; (3) give any contribution to the general public in increasing knowledge concerning about classroom action research and get any reflection for being perfection.

This research is done by the subject of the students of the second class of SMK Muhammadiyah Salatiga. Using "Think, Pair, Share" to improve their vocabulary. The researcher focused his research on improving vocabulary mastery and the students' interest in the process of teaching and learning using "Think, Pair, Share" method. The topic is Procedure Text. Using "Think, Pair, Share" method is to attract and encourage the students to improve their ability to construct their understanding and the ability to speak English and help the teacher to present the materials.

\section{The Review of Related Literature}

The researcher found some studies had been conducted using action research by (1) Prayuni (2012), In this research, she focuses on the psychological and characteristic factors of the students, they are motivation, relax and interest. Researcher through mind mapping as her method in the classroom. The result of her research in the students' achievement in English lesson, especially on vocabulary. (2) Hergenhalm in Elliott (1996) stated that good teaching begins with knowing what you want to 
teach: the stimuli, you must also identify the responses you want to connect to the stimuli and timing of appropriate satisfiers. (3) Erna (2006) in his research stated the way of teaching vocabulary as follow: The stages of teaching and learning vocabulary is divided into three stages which commonly known as presentation, practice, and production. (4) According to Richard, vocabulary is one of the most visible components of language, and one of the first things applied linguistic turned their attention (2001:4).

Vocabulary is the key to communication that will help someone in learning English. Without having a good vocabulary, someone will not be able to master and learn about foreign languages. Furthermore, vocabulary has a vital role in the teaching-learning process. The importance to learn vocabulary is as follows: (1) vocabulary is an essential element in the acquisition of a second language. (2) vocabulary is center to language especially for introducing new lexical items. (3) vocabulary is related to the word. (4) vocabulary is one step to know the word, understanding the meaning and used them in a sentence.

Vocabulary function is a productive and interactive skill. (1) What is productive skill? Concerning usage, it is then perfectly correct to say that vocabulary is productive and makes use of the aural medium. Widdowson (2003) described that the act of communication through vocabulary is commonly performed in face-to-face interaction and occurs as part dialogue or other forms of verbal exchange. What is said, therefore, is dependent on an understanding of what else has been said, whether by the speaker or the interlocutor in the interaction; (2) What is an interactive skill? Richards et al. (2000) stated that vocabulary is rarely done in one direction or the form of monologue. It involves the participation of the listener. In an interactive communication, a speaker, and therefore the speaker also becomes a listener.

Why "think, pair, share"? According to Arend (Trianto, 2007:61) say that TPS (Think, Pair, Share) is an effective way to diversify class discussion atmosphere. The procedure used in the TPS can give students' more to think and help each other. The procedure is applied explicitly to give students more time to think, respond, and share with their partners. Think-Pair-Share itself, as expressed by Lie (2002:57) that, "Think-Pair-Share is learning that gives students the opportunity to work independently and in collaboration with others. In this case, a significant role of teachers to guide students to the discussion, thus creating a learning atmosphere that is more alive, active, creative, effective and fun.

Think Pair Share learning model is followed by plenary discussion. With this learning model the students are trained in how to express their opinions and students also learn to respect others' opinion while referring to the material or learning objectives. TPS (Think-Pair-Share) learning model is a type of cooperative learning is designed to influence student interaction. TPS requires the student to work to help each other in small groups (2-4 students) and further detailed by the awarded cooperative, of the individual awards (Ibrahim et al.: 2000). 
Westwood, Peter, and Oliver (1979) stated the principles of oral language should be the language program of teaching vocabulary to be based on (1) create an enjoyable, entertaining, social learning situation, which gives pleasure to the students; (2) keep the peer work activity; (3) arrange for fragment, intensive sessions in two or three short sessions daily; (4) ensure active participation remembering that it is what a student practices saying, not what he hears, that improves communicating ability; (5) have clearly defined, short term goals for each session: teaching a particular adjective, adverb, or conjunction: 'and' and' but': (6) observe the slow learners and give some degree of repetition and our learning if necessary; (7) use material such as practices and games to hold attention as the basis for language simulation; (8) use pleasure and praise as reinforces.

Many native teachers are assigned listening and vocabulary classes, with limited opportunities to teach the other skills areas. There is, however, a general movement on many fronts to shift this once generic class towards more contentbased or ESP courses. The result has been that English now becomes more than a mere frill to the right vehicle to disseminate one's ideas. With the emergence of such a need, "think, pair,share" method can fill this gap because of the use of Think, Pair, Share in English learning process used to (1) note check (2) vocabulary review (3) quiz review (4) reading check (5) concept review (6) lecture check. Based on this process the students become more active in thinking about the concept of eye lessons, they can learn from other students. Each student in the group has the opportunity to share or convey his ideas.

The classes I was tough generally met twice a week for 90 minutes over 20 weeks. The underlying framework in the concept of cooperative learning especially in think, pair, share method where the groups' efforts are focused on accomplishing a meaningful task with shared rewards. Here is one of a group of two or three projects I carry out during a week.

\section{Method}

The method used in this research was classroom action research (CAR) focused on using think, pair, share to improve vocabulary mastery. The subject of the research the students of SMK Muhammadiyah in the academic year of 2011/2012. It is only one class consist of 35 students. They are 34 boys and one girl. According to Elliot's action research model (2008: 64), the procedures are briefly described in the following scheme: 
109 | VISION: JOURNAL FOR LANGUAGE AND FOREIGN LANGUAGE LEARNING

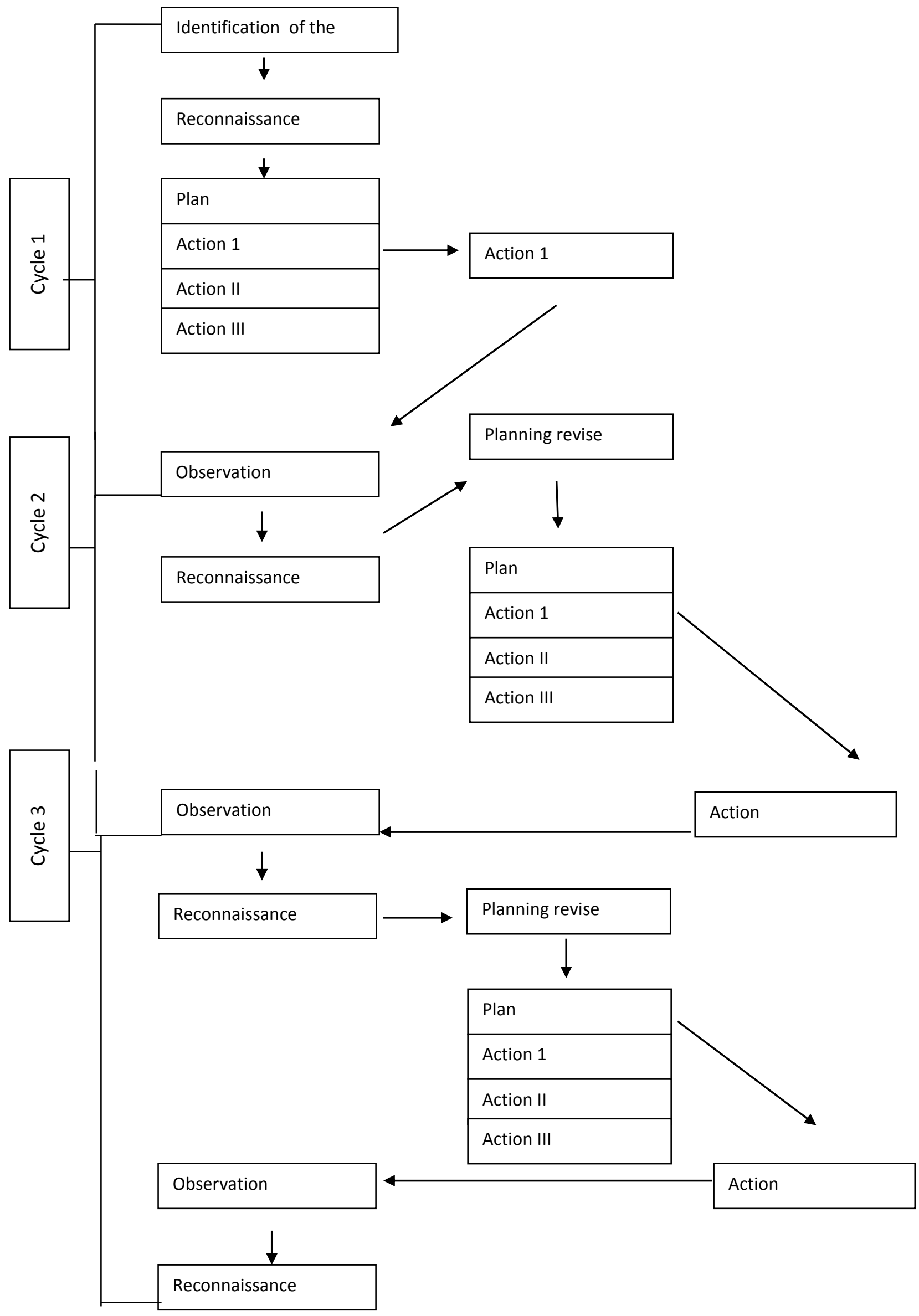


Based on the explanation about procedure of action research above, the researcher has arranged three cycles. In each cycle, the steps are planning, acting, observing and reflection.

To collect data, the instruments to be used: (1) test consisted of pretest, post-test, and formative test; (2) observation. Test after the first treatment and test after the second treatment administered to find out the improvement of the students' vocabulary ability, the formative test was administered to measure about the improvement of their vocabulary ability from the cycle 1 , cycle 2 and cycle 3 . The observation was administered to measure the characteristics of the students towards the application of using think, pair, share, and a questionnaire was administered to support the data of the students' improvement in vocabulary mastery.

The activities of the research used the following procedures:

1. The researcher observed the previous students' vocabulary average.

2. The researcher planned the action, constructing the lesson plan for the first cycle using think, pair, share.

3. The researcher implemented the first action cycle (giving treatment, using think, pair share).

4. The researcher observed the classroom while implementing the actions in the first cycle.

5. The researcher gave reflection to the results of the observation by using the guide of observation in the form of checklist.

6. The researcher analyzed the result and then classified them qualitatively.

7. The researcher constructed the lesson plan for the second cycle.

8. The researcher implemented the second action cycle.

9. The researcher observed the classroom while implementing the second action cycle.

10. The researcher reflected the results of class observation in the second cycle.

11. Analyzing the results of writing test in the second cycle quantitatively and then classified them qualitatively,

12. The researcher constructed the lesson plan for the third cycle.

13. The researcher implemented the third action cycle.

14. The researcher observed the classroom while implementing the third action cycle.

15. The researcher reflected the results of class observation in the third cycle.

16. Analyzing the results of writing test in the third cycle quantitatively and then classified them qualitatively, 
In the first treatment, the researcher did some activities related to the using of think, pair, share. The theme chosen was Procedure Text. The first treatment activities were:

\section{a. Warm up:}

1. Opening. This activity is as like greeting and asking students' condition.

2. Brainstorming to the matter. This activity was done to guide students to the matter given.

3. Distributing the procedure text.

\section{b. Whilst:}

1. The teacher asked the students to guess the title and asking the vocabulary related to the picture.

2. The teacher wrote the difficult vocabularies related to the picture on the board.

3. The teacher drilled the difficult vocabulary related to the pictures.

4. The teacher asked them to discuss with their partners about the procedure text.

5. The teacher asked them to tell the pictures how to make something.

\section{c. Closing}

1. The teacher asked their difficulty and their problem in vocabulary process.

2. The teacher gave motivation in studying and closing the lesson.

From the first treatment, the research got the problem as below:

1. The pictures were not so interesting.

2. The students got difficulty in contracting the sentence, because many new vocabularies for them, so they need a long time to memorize.

3. The researcher needed to pay attention more to the students who were weak in vocabulary in guided them to make the story.

After analyzing the problem above, the researcher needs to solve the problem. So on the second treatment, the researcher would be accessible in attempting the method. Then after choosing the interesting pictures, the researcher made a lesson plan. Then the researcher did some activities in implementing the second treatment. The treatment was as follow; 


\section{a. Warm up:}

1. Opening. This activity is as like greeting and asking students' condition.

2. The teacher gave the brainstorming to the matter. This activity was done to guide students to the matter given.

3. The teacher distributed procedure text.

\section{b. Whilst:}

1. The teacher asked them to pay attention to the picture.

2. The teacher asked the students to guess the picture and asking the vocabulary related to the picture.

3. The teacher wrote the difficult vocabularies related to the picture on the board.

4. The teacher drilled the difficult vocabulary related to the pictures.

5. The teacher asked them to discuss with their partners.

6. The teacher asked them to present their idea in their group first.

7. The teacher asked each group to give correction and suggestion to their friend's error.

8. After the correction, the teacher asked every student to tell the pictures in front.

9. The teacher asked another friend to give suggestion and correction

\section{c. Closing}

1. The teacher asked their difficulty and their problem in vocabulary process.

2. The teacher gave motivation in studying and closing the lesson.

Based on those activities, the problems on the first treatment could be eliminated. Here, the researcher gave more assistance and support to the weak students. Besides that, the correction and suggestion from their partner in pair work could eliminate the error when they share their result in front. The theme about procedure text is so interesting and made them enthusiastic to share with another group.

\section{Data Analysis}

From the result of analyzing in cycle 1 , cycle 2 , and cycle three the researcher will analyze the students' improvement from cycle 1 , cycle 2 , and cycle 3 . 
Table 5. The analyze of students' improvement

\begin{tabular}{|c|c|c|c|c|}
\hline \multicolumn{5}{|l|}{$\mathrm{o}$} \\
\hline \multirow[t]{5}{*}{1} & MEAN & & & \\
\hline & - PRE-TEST & 40 & 66,0 & 70,0 \\
\hline & - POST-TEST &, 14 & 5 & 5 \\
\hline & & 50 & 76,0 & 81,5 \\
\hline & & ,42 & 5 & 7 \\
\hline \multirow[t]{2}{*}{2} & T-TABLE $\mathrm{N}=34$ & 2, & 2,04 & 2,04 \\
\hline & & 042 & 2 & 2 \\
\hline 3 & $\begin{array}{l}\text { T- } \\
\text { CALCULATION(T- } \\
\text { TEST) }\end{array}$ & $4^{5}$ & 6,32 & 8,03 \\
\hline
\end{tabular}

If table calculation same or greater than t-calculation, so null hypothesis (Ho) is rejected. Ho is no significant difference between pretest and posttest.

From the t-test calculation above is greater than t-table. So, Ho is rejected therefore there is no significant between pretest and posttest. It shows that think, pair, share method gives influence in improving students' vocabulary mastery.

From the statement above, the researcher can see that mean between pre-test and post-test has significant different, where post-test is greater than pre-test. It shows that think, pair, share method learning gives influence in improving students' vocabulary mastery because the students' achievement has been increased after the students' did a picture. Moreover, in cycle three the students' comprehension used power point in the teaching-learning process with theme procedure text, students' achievement very increase. It means it is appropriate with the situation and condition of students' in SMK Muhammadiyah Salatiga in learning English especially in vocabulary beside that, the students are more interested and can be active in the teaching-learning process.

\section{Conclusion and Suggestion}

\section{Conclusion}

Based on the explanation above, the researcher concludes that the use of Think, Pair, Share in teaching English as follows:

a) The researcher concludes that the use of Think, Pair, Share learning method in teaching vocabulary to the students SMK Muhammadiyah can improve students' vocabulary mastery. For the result of the research show that Think, Pair, Share learning model can help the students' to improve their vocabulary mastery from 
the t-test calculated. The result of t-test calculation with $n=32$ is 2,042 in cycle I is 5,49 , cycle II is 6,32 , cycle III is 8,03 . If t-table same or greater than $\mathrm{t}$ calculation, so the null hypothesis (Ho) is no significant difference between pretest and post-test mean. From the t-test calculation above is greater than t-table. So, Ho is rejected. Therefore there is a significant difference between pre-test and post-test mean. Besides that, the students' more interested and involved actively in the teaching-learning process.

b) From the statement above, the researcher can see that the mean between pre-test and post-test has a significantly different, where post-test is greater than pre-test. It shows that Think, Pair, Share learning method gives influence in improving students' vocabulary because the students' achievement has been increased after the students' did the method in learning English. It means that Think, Pair, Share method is appropriate with the situation and condition of students in SMK Muhammadiyah in learning English, especially in vocabulary. Besides that, the students' are more interested and involved actively in the teaching-learning process.

\section{Suggestion}

Based on the result of the study and conclusion, the researcher would like to suggest as follows:

a) The teacher

The teacher should enhance the student's ability in teaching English especially when he taught using Think, Pair, Share learning method to improve vocabulary mastery, so the students' will remember the words easily. The teacher should teach vocabulary effectively. So, teacher role in the teaching-learning process can influence students in improving students' vocabulary mastery. Besides, the teacher asked the students to study English.

b) To the students

Students should always be active in the teaching-learning process and are not afraid of English lesson; students should study English continually in classroom and their home. When teaching vocabulary, the students pay attention to the teacher's explanation.

c) To the researcher

It has been known from the result of the study using Think, Pair, Share learning method that it can improve the students' vocabulary mastery. As a result of this, it is hoped that the result of the study makes the English teacher use an appropriate teaching mode of presentation on improving students' vocabulary mastery. Based on the explanation the researcher would like to suggest other researchers, the result of the study can be used as an additional reference for a further researcher with the different sample and occasions. 


\section{References}

Amin Moh, M.Pd. (2011). Panduan Praktis Penelitian Tindakan Kelas. Yogyakarta: Inspirasi

Brown, R. S, and Nation, P. (1997). Teaching Vocabulary: Suggestion for the Classroom.

Elliott et al. (1996). Educational Psychology, Effective Teaching, Effective Learning.

Huda Miftahul.2011.Cooperative Learning. Yogyakarta: Pustaka Pelajar

Hayati Fatma.Model Pembelajaran Think pair share ( http:/ghiffart. multiply. $\mathrm{com} /$ journal/item/is text/ html)

IKIP PGRI Madiun. (2006). Dharma Pendidikan: Jurnal Pendidikan dan Pembelajaran. Nganjuk.

Mod36_coop_think_pair_share.pdf retrieved 01 February 2012 at 19.30

Nunan, David P. (1991). Learning Teaching Methodology: A Textbook for Teacher. New York. Prentice Hall.

Prof.Dr.Wiriaatmadjarochiati. (2008).MetodePenelitian Tindakan Kelas.Bandung: PT.Remaja Rosda Karya

Prasetyo Bambang, Jannah Miftahul Lina. (2011). Metode Penelitian Kuantitatif. Jakarta: PT. Raja Grafindo Persada

Thornbury Scott. (2002). How To Teach Vocabulary. England: Pearson Education Limited

Rivers, Wilga M. (1968). Teaching Foreign Language Skills. New York: The University of Chicago.

Rodgers S. Theodore, Richards C. Jack. Approaches and Methods in Language Teaching. New York: Cambridge University Press 